\title{
Corporate Sustainability and Responsibility
}

By Benedict Sheehy ${ }^{1} \&$ Mark Anthony Camilleri ${ }^{2}$

Suggested Citation: Sheehy, B. \& Camilleri, M.A. (2021). Corporate Sustainability and Corporate Social Responsibility. In Idowu, S., Schmidpeter, R., Capaldi, N., Zu, L., Del Baldo, M. \& Abreu, R. (Eds.), Encyclopedia of Sustainable Management, Springer, Cham, Switzerland. https://doi.org/10.1007/978-3-030-02006-4_397-1

This is a prepublication version.

\begin{abstract}
The Corporate Social Responsibility 'CSR' notion is increasingly drawing the attention of a number of academic authors. Very often, they are using CSR as well as Corporate Sustainability, without clearly distinguishing the differences in their meanings. This contribution defines the meaning of corporate sustainability and responsibility.
\end{abstract}

\section{INTRODUCTION}

The terms Corporate Social Responsibility 'CSR' and Corporate Sustainability tend to be used either interchangeably, or without clear attention to the difference. The terms focus on different but related areas of activity: business management, social action and the natural environment.

In its essence, CSR is a form of international private business regulation focused on enterprises' environmental and social impacts (Sheehy, 2015). It includes a host of individual and collective rights as well as ethical and environmental issues. It has been a bottom-up push focused on business which has led to a response from global policy makers (Kuper, 2005; Rasche \& Waddock, 2014; Sheehy, 2017a, 2017b; Voegtlin \& Pless, 2014). By way of contrast, corporate

\footnotetext{
${ }^{1}$ 1.Canberra Law School, University of Canberra, Canberra, Australia.

${ }^{2}$ Department of Corporate Communication, Faculty of Media and Knowledge Sciences, University of Malta,, Msida, Malta. Email: $\underline{\text { mark.a.camilleri@um.edu.mt }}$
} 
sustainability is a rather diverse set of ideas originating from environmentally focused activists, global development groups and environmental professionals and specialists focused on business. Finally, although both terms refer to the concept of business ethics, they do so in quite different ways.

Both terms are added to the broader term sustainability. For example, accounting scholars Bebbington and Gray (1997) integrate the terms sustainability, sustainable development and business stating, "at a minimum, the sustainable business is one that leaves the environment no worse off at the end of each accounting period than it was at the beginning". This use conflates the terms with the global public policy agenda of sustainable development, most recently enacted as the Sustainable Development Goals.

\section{CORPORATE SOCIAL RESPONSIBLITY}

CSR has been part of the business dialogue for since the late 1920's. Two law scholars argued about the role and obligations of company directors. One argued that corporate managers were responsible solely to shareholders while the other argued that the corporate managers were statesmen [sic] to use their powers for the betterment of society (Sommer, 1991). The debate was taken forward through the 1950's with Bowen's classic work, the Social Responsibilities of the Businessman (Bowen, 1953). A range of further developments in the business-andsociety discussions expanded the concept and obligation drawing in ever more concerns and parties leading to a vagueness around the term (Camilleri, 2017). Archie Carroll created order by producing a hierarchical pyramid for categorising and prioritising business obligations when considering business-society relations (Carroll, 1991). 


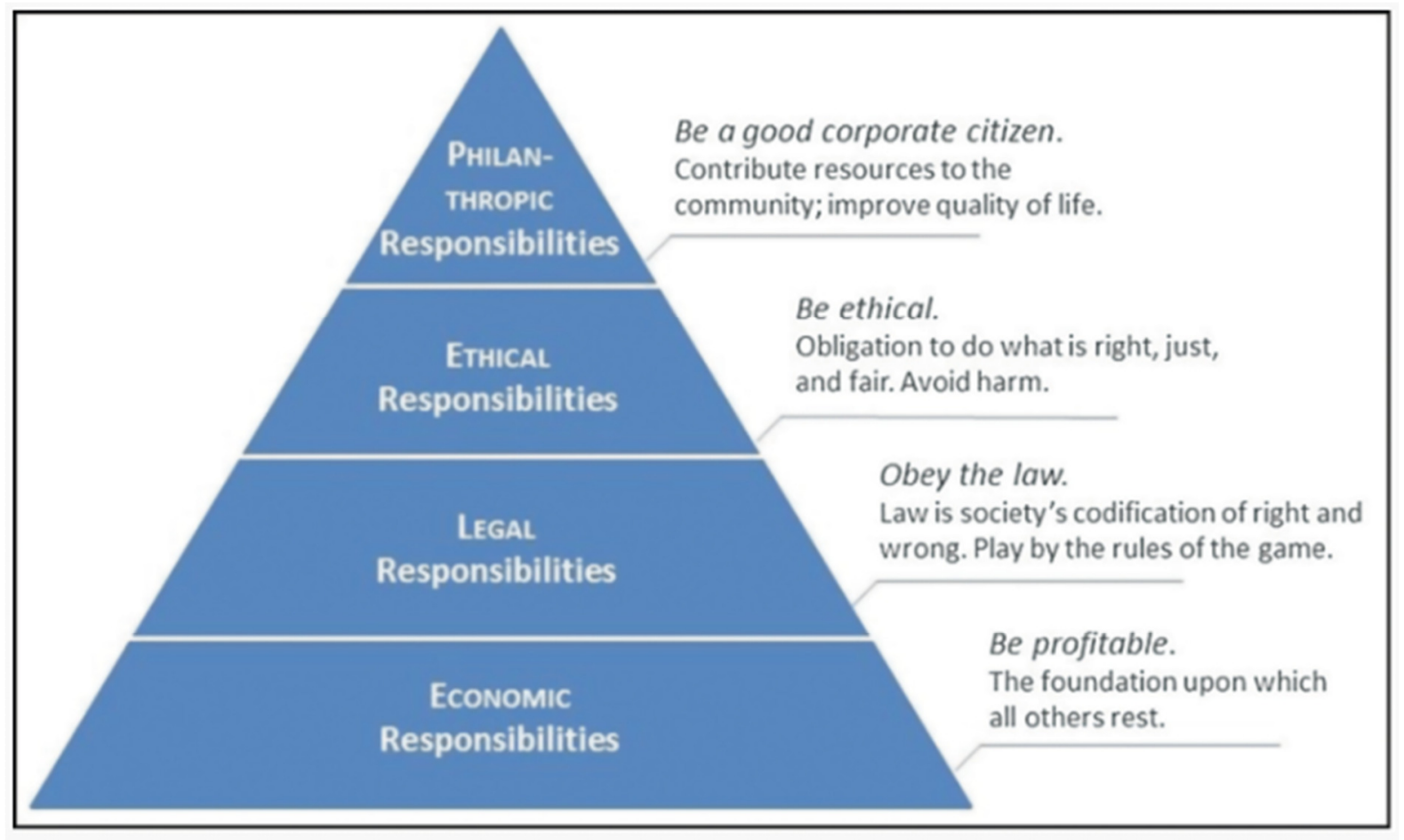

Fig. 1

Carroll's CSR Pyramid

Carroll proposed dividing CSR into four tiers of responsibilities prioritised from basic ones at the bottom to the ethical ones at the top. Carroll argued that the first responsibility is to be economically sound, then secondly to comply with law. The third level of responsibility he posited was ethical. Executives were avoiding harm and contribute to positive justice by treating other parties fairly. Finally, at the top level, once all other obligations had been fulfilled, Carroll argued that the firm has philanthropic obligations.

CSR in theory and practice has developed slowly from consideration of directors' obligations, through hierarchy of management choices, to the point where it can now be properly defined as: "international private business self-regulation" (Sheehy, 2015). Sheehy's definition draws in international soft law norms directed at business organisations. In this definition, CSR is understood as regulatory in that it is a set of norms aimed at effecting business behaviour-a type of soft law, rather than a business strategy. 


\section{CORPORATE SUSTAINABILITY}

Corporate Sustainability is a concept that is significantly different from CSR. Like CSR, corporate sustainability accepts the view that companies have a wider responsibility beyond profit, (Hahn \& Figge, 2011), 325). Unlike CSR, however, corporate sustainability is a much more recent concept with roots in environmental and global policy. In the former, it grew out of the corporate environmental movement, which arose in the 1970's to address a range of environmental disasters that captured public attention (Sheehy, 2019).

Corporate environmentalism, however, was not an end point and environmental concerns about industry were swept up in economic and political globalisation marked by among other things, the increase in power of multinational enterprises over the intervening decades (Osterhammel \& Petersson, 2005; Scholte, 2005). In this intervening period, business came to be viewed as a 'partner' in society, and in this case, a global development partner. The term corporate sustainability thus arises from this confluence of concerns and the dynamic political landscape. The term corporate sustainability took on additional meaning as part of the effort to bring business into alignment with the UN's development program, the Sustainable Development Goals (SDG's).

The term "sustainability" can mean different things to a variety of constituencies. While there may be no objection to the sentiments expressed by multiple stakeholders on the respective definitions for sustainable business, most of them are far from holistic. The sustainability systems may be too complex and varied, and their applications could be quite diverse. Some authors have attempted to relate sustainability with the corporations' responsible behaviours (Camilleri, 2017). Dyllick and Hockert's widely accepted definition of the term "corporate sustainability" is most useful. They define corporate sustainability as "meeting the needs of a firm's direct and indirect stakeholders (such as shareholders, employees, clients, pressure groups, communities etc.), without compromising its ability to meet the needs of future 
stakeholders as well" (Dyllick \& Hockerts, 2002). Their definition makes no explicit mention of environment although it is certainly implied. Others such Hahn and Figge state that "there seems to be some implicit pragmatic consensus that corporate sustainability refers to some composite and multi-faceted construct that entails environmental, social, and economic organizational outcomes" (Hahn \& Figge, 2011) 327. These pillars are interconnected to each other where the economy is part of society, which is also a fundamental part of the larger ecological system. Corporate sustainability relies on six criteria: eco-efficiency, socioefficiency, eco-effectiveness, socio-effectiveness, sufficiency and ecological equity (Dyllick \& Hockerts, 2002). These corporate sustainability imperatives can be structured into value systems that could result in a better financial performance (Salzmann, Ionescu-Somers \& Steger, 2005; Van Marrewijk, 2003). A few researchers have developed (self)-assessment tools, that could be used to audit, analyse and interpret corporate sustainability (Van Marrewijk, 2003). However, corporate sustainability may be contingent on different parameters (e.g. technology, regime and visibility) that could vary across industries, plants and countries (Salzmann et al., 2005). Corporate sustainability could reduce the downside operational risk as it comprises relevant measures that are intended to increase eco-efficiency, and health and safety performance among other issues (Porter \& Kramer, 2019; Camilleri, 2014). This means that the economic value of sustainable business strategies could be materialised in the longterm (Weber, 2008).

Notwithstanding, there are the long term effects of corporate sustainability on intangible assets (e.g. brand value, employee loyalty) could be difficult to quantify (Salzmann et al., 2005; Dyllick \& Hockerts, 2002). Although some commentators have voiced their opposition to the normative calls in favour of the "sustainability rhetoric" (Salzmann et al., 2005), it may appear that we are witnessing a relentless progression from active antagonism, through indifference, to a strong commitment to actively furthering sustainability values, not only within the 
organization, but across many industries and in our society as a whole. These recent developments imply that the organizations' commitment to responsible behaviours may represent a transformation of the corporation into a truly sustainable business that is adding value to the business itself, whilst also adding value to society and the environment (Camilleri, 2016).

Beyond management disciplines, the term corporate sustainability refers to the assessment of business conduct with reference to the ecological limitations of the planet. Beginning with the limitations of the earth's ecosystems, this group of scholars works down to the level of industrial production to argue that for sustainability reasons, businesses must change their methods of production as part of a larger change society must have with respect to its relationship with the environment (Sjåfjell \& Richardson, 2015).

\section{CONCLUSION}

Corporate sustainability and CSR are related but distinct concepts. Corporate sustainability is derived from the corporate environmental movement. In contemporary use, it is a concept that begins with an analysis of the limitations of the earth's ecosystems. It then works down to the implications for business organisations. By way of contrast, CSR is form of international soft law directing business behaviour to align with global norms touching on social and environmental practices as well as corporate governance.

\section{REFERENCES}

Bowen, H. (1953). Social Responsibilities of the Businessman. New York: Harper \& Row. Camilleri, M. (2014). Advancing the sustainable tourism agenda through strategic CSR perspectives. Tourism Planning \& Development, 11(1), 42-56.

Camilleri, M. A. (2016). The Corporate Sustainability and Responsibility Proposition: A Review and Appraisal. In Camilleri, M.A. (Ed.) CSR 2.0 and the New Era of Corporate Citizenship. Hershey, USA: IGI Global. 
Camilleri, M. A. (2017). Corporate sustainability and responsibility: creating value for business, society and the environment. Asian Journal of Sustainability and Social Responsibility, 2(1), 59-74.

Carroll, A. B. (1991). The Pyramid of Social Corporate Responsibility. Business Horizons, July-August, 39-50.

Dyllick, T., \& Hockerts, K. (2002). Beyond the business case for corporate sustainability. Business Strategy and the Environment, 11(2), 130-141. doi:10.1002/bse.323

Hahn, T., \& Figge, F. (2011). Beyond the bounded instrumentality in current corporate sustainability research: Toward an inclusive notion of profitability. Journal of Business Ethics, 104(3), 325-345.

Kuper, A. (2005). Redistributing Responsibilities--The UN Global Compact with Companies. In A. Follesdal \& T. Pogges (Eds.), Real World Justice: Grounds, Principles, Human Rights, And Social Institutions: Springer.

Osterhammel, J., \& Petersson, N. P. (2005). Globalization: A Short History. Princeton, NJ: Princeton University Press.

Porter, M. E., \& Kramer, M. R. (2019). Creating shared value. In Managing sustainable business (pp. 323-346). Springer, Dordrecht.

Rasche, A., \& Waddock, S. (2014). Global Sustainability Governance and the UN Global Compact: A Rejoinder to Critics. Journal of Business Ethics, 122(2), 209-216.

doi:10.1007/s10551-014-2216-6

Scholte, J. A. (2005). Globalization: A Critical Introduction (2nd ed.). Basingstoke, UK, New York: Palgrave Macmillan.

Sheehy, B. (2015). Defining CSR: Problems and Solutions. Journal of Business Ethics, 131(3), 625-648. doi:10.1007/s10551-014-2281-x

Sheehy, B. (2017a). Conceptual and Institutional Interfaces among CSR, Corporate Law and the Problem of Social Costs. Virginia Law \& Business Journal, 12(1), 95-145. Retrieved from Available at SSRN: http://ssrn.com/abstract=2156751

Sheehy, B. (2017b). Private And Public Corporate Regulatory Systems: Does CSR Provide A Systemic Alternative To Public Law? UC Davis Business Law Journal, 17, 1-55. Retrieved from http://ssrn.com/abstract=2157316

Sheehy, B. (2019). CSR and Environmental Law: Concepts, Intersections, and Limitations. In A. McWilliams, D. E. Rupp, D. S. Siegel, G. K. Stahl, \& D. A. Waldman (Eds.), The Oxford handbook of corporate social responsibility (2nd ed., pp. 261-282). Oxford and New York: OUP.

Sjåfjell, B., \& Richardson, B. J. (2015). Company Law and Sustainability: Cambridge University Press.

Sommer, A. A. J. (1991). Whom Should the Corporation Serve--The Berle-Dodd Debate Revisited Sixty Years Later. Delaware Journal of Corporate Law, 16.

Salzmann, O., Ionescu-Somers, A., \& Steger, U. (2005). The business case for corporate sustainability: literature review and research options. European Management Journal, 23(1), 27-36.

Van Marrewijk, M. (2003). Concepts and definitions of CSR and corporate sustainability: Between agency and communion. Journal of business ethics, 44(2-3), 95-105.

Voegtlin, C., \& Pless, N. M. (2014). Global Governance: CSR and the Role of the UN Global Compact. Journal of Business Ethics, 122(2), 179-191. doi:10.1007/s10551-014-2214-8 Weber, M. (2008). The business case for corporate social responsibility: A company-level measurement approach for CSR. European Management Journal, 26(4), 247-261. 
